\title{
Nye direktevirkende antikoagulasjonsmidler til kreftpasienter?
}

\author{
Det er ikke kontraindisert å gi de nye direktevirkende antikoagulasjonsmidlene til pasienter med kreft, men \\ det anbefales ikke - på grunn av manglende dokumentasjon. Er det likevel forsvarlig å gi disse legemidlene \\ til denne pasientgruppen?
}

I løpet av de siste fire til fem årene har de direktevirkende orale antikogulasjonsmidlene (DOAK) dabigatran, rivaroksaban, apiksaban og sist edoksaban erstattet warfarin som førstevalget $\mathrm{i}$ behandlingen av venøs trombose. Hos kreftpasienter, derimot, er lavmolekylært heparin førstevalget, siden man i to randomiserte, kontrollerte studier med kreftpasienter med venøs trombose fant at lavmolekylært heparin ga færre residivtromboser enn warfarin $(1,2)$.

Det er foreløpig ikke gjort noen randomisert, kontrollert studie med kreftpasienter der man sammenligner de nye antikoagulasjonsmidlene med lavmolekylært heparin. De store fase 3-studiene av venøs trombose i den generelle befolkningen der DOAKbehandling ble sammenlignet med warfarinbehandling, inkluderte kun noen få kreftpasienter (3). Disse er trolig ikke representative for de kreftpasientene som vanligvis behandles for venøs trombose, for eksempel ble pasienter med forventet levetid under tre eller seks måneder ikke inkludert.

Residivtromboser og blødninger er de viktigste endepunktene i studier om antikoagulasjonsbehandling for venøs trombose. Foreløpig mangler dokumentasjon på begge deler hos kreftpasienter. Av den grunn anbefales ikke de nye antikoagulsjonsmidlene ved kreftrelatert venøs trombose (4-6). Er det likevel forsvarlig å gi disse midlene til kreftpasienter?

\section{Kreftpasienter er ekstra utsatt for interaksjoner og blødninger} Alle de nye direkte perolale antikoagulasjonsmidlene interagerer med medikamenter som påvirker P-glykoprotein og CYP3A4, for eksempel mange medisiner mot hivinfeksjon, mange antiepileptika og mange midler mot soppinfeksjon.

Kreftpasienter som får venøs trombose, er som regel under behandling for sin kreft. Mange får soppmidler - enten forebyggende eller som behandling. Trolig kan ikke soppmidlene vorikonazol og posakonazol brukes sammen med de nye direkte perolale antikoagulasjonsmidlene grunnet interaksjon, kanskje heller ikke flukonazol.

I forbindelse med oppstart av CAP-studien (Apixaban som behandling for kreftrelatert venøs trombose) gikk studieledelsen (bl.a. undertegnede A.E.A. Dahm) gjennom kreftmedisiner som brukes i Norge og er registrert i Felleskatalogen og forhørte seg med Statens legemiddelverk med tanke på interaksjon med apiksaban. Det ble funnet at dabrafenib (mot malignt melanom), idelalisib (mot kronisk lymfatisk leukemi og follikulært non-Hodgkins lymfom), enzalutamid (mot prostatakreft) ikke kan brukes sammen med apiksaban på grunn av interaksjon. Dette var ukjent både for produsenten av apiksaban og for kreftlegene som deltar i studien.

Medikamentelle interaksjoner er ikke alltid mulig å forutsi ut fra hvilke enzymer de metaboliseres av, og det oppstår derfor

\section{«Det er vanskelig å skaffe nok pasienter til å gi statistisk styrke til å avklare om DOAK- behandling er like bra som behandling med lavmolekylært heparin»}

ofte uventede interaksjoner. Listen over medisiner som kanskje kan interagere med de nye direkte perolale antikoagulasjonsmidlene er veldig lang. I vår gjennomgang fant vi 49 som potensielt kan interagere, deriblant glukokortikoider, kvalmestillende medikamenter, antibiotika, kreftmidler og immundempende medisiner. Alle disse medikamentgruppene brukes hyppig av kreftpasienter, og uten kliniske studier vil vi ikke kunne finne ut om interaksjon med de nye antikoagulsjonsmidlene er viktig eller ikke.

Kreftpasienter er også utsatt for trombocytopeni på grunn av benmargssvikt forårsaket av kjemoterapi. Vi har forholdsvis lang erfaring med hvordan vi håndterer trombocytopeni hos pasienter som bruker lavmolekylært heparin, men vi har ingen erfaring med DOAK-bruk hos trombocytopene pasienter. Disse midlene har en halveringstid som er to til fire ganger så lang som halveringstiden til lavmolekylært heparin, og det er mulig vi bør ha andre forholdsregler enn ved lavmolekylært heparin.

Det er altså gode grunner til å være forsik- tig med å gi nye direkte perolale antikoagulasjonsmidlene til kreftpasienter: Det mangler dokumentasjon når det gjelder residivtromboser og blødninger. Videre kan for eksempel medikamentinteraksjoner og trombocytopeni skape problemer vi ikke har mulighet til å forutsi - uten kliniske studier.

\section{Kommende studier hos kreftpasienter}

Det pågår flere studier av de nye antikoagulasjonsmidlene hos kreftpasienter, blant annet den norske CAP-studien. Problemet med de randomiserte, kontrollerte studiene av kreftrelatert venøs trombose er at det er vanskelig å skaffe nok pasienter til å gi statistisk styrke til å avklare om DOAKbehandling er like bra som behandling med lavmolekylært heparin. Et rimelig anslag er at man trenger $3000-4000$ pasienter, men foreløpig er det ikke planlagt studier i denne størrelsesorden. Likevel vil vi i løpet av de neste tre til fem årene uansett få vite mye mer om de nye midlene brukt ved kreftrelatert venøs trombose enn vi gjør nå.

Da de nye direkte perolale antikoagulasjonsmidlene ble tilgjengelig i Norge, var det mange som mistenkte at de ville bli tatt i bruk hos kreftpasienter på tross av manglende dokumentasjon, siden peroral administrasjon er enklere. Vår erfaring er at dette stemmer. Vi ser stadig oftere kreftpasienter som får behandling med slike legemidler. Dette er en risikabel praksis - inntil det foreligger studier som faktisk viser at midlene trygt og effektivt kan brukes hos mennesker med kreft.

\section{Anders Erik Astrup Dahm \\ aeadahm@gmail.com \\ Waleed Ghanima}

Anders Erik Astrup Dahm (f. 1968) er overlege i hematologi ved Avdeling for blodsykdommer, Akershus universitetssykehus, førsteamanuensis ved Institutt for klinisk medisin, Universitetet i Oslo, og nasjonal koordinerende hovedutprøver for CAP-studien.

Forfatter har fylt ut ICMJE-skjemaet og oppgir følgende interessekonflikter: Han har mottatt forskningsstipend fra Pfizer Norge, honorar fra Bristol-Myers Squibb, Novartis Norge og Pfizer Norge og reisestøtte fra Celgene. 
Waleed Ghanima (f. 1964) er overlege i hematologi ved Avdeling for blodsykdommer, Oslo universitetssykehus, forskningssjef ved Sykehuset $\emptyset$ stfold og førsteamanuensis ved Institutt for klinisk medisin, Universitetet i Oslo.

Forfatter har fylt ut ICMJE-skjemaet og oppgir følgende interessekonflikter: Han har mottatt foredragshonorar fra Boehringer Ingelheim, BMS/Pfizer, Bayer Healthcare, Novartis og Roche.

\section{Litteratur}

1. Lee AY, Levine MN, Baker RI et al. Low-molecularweight heparin versus a coumarin for the prevention of recurrent venous thromboembolism in patients with cancer. N Engl J Med 2003; 349: 146-53.

2. Lee AY, Kamphuisen PW, Meyer $G$ et al. Tinzaparin vs Warfarin for Treatment of Acute Venous Thromboembolism in Patients With Active Cancer: A Randomized Clinical Trial. JAMA 2015; 314: 677-86.

3. Vedovati MC, Germini F, Agnelli $G$ et al. Direct oral anticoagulants in patients with VTE and cancer: a systematic review and meta-analysis. Chest 2015 147: 475-83.

4. Kearon C, AkL EA, Ornelas J et al. Antithrombotic Therapy for VTE Disease: CHEST Guideline and Expert Panel Report. Chest 2016; 149: 315-52.

5. Farge D, Debourdeau P, Beckers M et al. International clinical practice guidelines for the treatment and prophylaxis of venous thromboembolism in patients with cancer. J Thromb Haemost 2013; 11: 56-70.

6. Lyman GH, Bohlke K, Falanga A. Venous thromboembolism prophylaxis and treatment in patients with cancer: American Society of Clinical Oncology clinical practice guideline update. J Oncol Pract 2015; 11: e442-4.

Mottatt 3.1.2017, første revisjon innsendt 12.1.2017. godkjent 13.1. 2017. Redaktør: Ketil Slagstad.

Publisert først på nett. 